\title{
A Prospective study of avoidable domestic factors in fatal thermal injuries in a tertiary care hospital
}

\author{
Pradeep K Nayak ${ }^{1}$, Sujan K Mohanty ${ }^{2 *}$, Priyambada Behera ${ }^{3}$ \\ ${ }^{1,2}$ Assistant Professor, ${ }^{2}$ Associate Professor, ${ }^{3}$ Senior Resident, ${ }^{1-3}$ Dept. of FMT, ${ }^{\mathbf{1 - 2}} \mathrm{Hi}$-Tech Medical College,Bhubaneswar, ${ }^{3}$ SCB Medical \\ College, Cuttack, Odisha, India \\ *Corresponding Author: Sujan Kumar Mohanty \\ Email: suju2411@yahoo.in
}

\begin{abstract}
Thermal burns and related physical injuries (electrocution and lightening) are major causes of death and disability in India. This is largely related to the geographical distribution, nature of domestic appliances, wearing apparels or clothes and use of wood, leaves, straw, open chullha, kerosene stove, kerosene lamps, etc. for cooking, heating and lighting purpose. A prospective study on deaths due to thermal injuries was conducted at a tertiary care hospital over a period of two years. Accidental burn by flame or fire during cooking inside the house is the most common cause and majority of the victims are females in their third decade from rural background. Around $1 / 6^{\text {th }}$ of burn deaths were suicidal using kerosene. Majority of the victims wore synthetic clothes. Well ventilated pucca houses, safer LPG stoves, early hospitalisation and prompt referral with public awareness should be encouraged to minimise the morbidity and mortality due to thermal injury.
\end{abstract}

Keywords: Accidental burns, Cooking, Females, Kerosene, Suicidal, Synthetic clothes.

\section{Introduction}

A Burn is an injury which is caused by application of heat or chemical substances to the external or internal surfaces of the body, which causes destruction of tissues ${ }^{1}$.Thermal burns and related physical injuries are major causes of death and disability affecting the entire world and more so to the developing countries like India. According to World Health Organisation, Department of Measure and Health information, April 2011, out of 59.7 /100000 unintentional injuries reported in India, death rate of 4.6/100000 are due to death by fire.

Most of the Indian population live in rural areas where many women (housewives) spend their maximum time in the household especially in the kitchen. A similar scenario also prevails in urban culture of India though little less in comparison to rural population. Burn injuries are one of the greater morbidity and mortality factor for Indian population, especially in females. The extent of burn injuries in developing countries like India is largely related to the geographical distribution, nature of domestic appliances, the typical wearing apparels or clothes etc. Conventional methods like wood, leaves, straw, open chullha, kerosene stove, kerosene lamps, LPG and natural gas stove etc. are used for cooking, heating and lighting purpose. Custom of wearing loose fitting garments like sarees or dupatta in females is also an important factor.

In the current study, the domestic factors affecting the fatal burn injuries are analysed and how the modification of certain factors may affect the outcome of burn injuries are discussed.

\section{Materials and Methods}

A prospective study was conducted at S.C.B Medical College \& Hospital, Cuttack from September 2012 to August 2014. A total of 301 cases of deaths due to thermal injuries as a result of local exposure to heat, which were brought for autopsy to this tertiary care hospital, were included in the study excluding the post-mortem burns. The burn wounds caused due to physical injuries such as electrocution and lightening were also included. No incidence of hypothermic deaths was reported. Case histories were taken from the attendant of the deceased, accompanying police personnel, inquest report \& dead body challan. The results were studied and analysed in detail with special reference to household burns and domestic factors.

\section{Result}

Deaths due to burns (flame/dry heat) were the most $(92.4 \%)$ among all types of thermal deaths, while deaths due to scalds (moist heat) were the least $(2 \%)$. Most of the deaths were due to thermal burn injuries in both females and males. But males outnumbered females in lightening and electrocution fatality. (Table 1) In all types of burn deaths, Female victims (76.4\%) outnumbered males. (Fig.1)The peak incidence was observed in the age group of 21-30 years $(39.8 \%)$ followed by $11-20$ years $(26.2 \%)$. The most susceptible age group for both male and female is 21-30 years followed by age group of 11-20 years in female and 31-40 years in males. (Table 2) Predominantly the victims are from rural community $(74.4 \%)$ with almost similar preponderance to each gender. (Table 3) Almost all female burn victims suffered the thermal injury inside the four walls of house i.e. kitchen \& living rooms while all the industrial burn victims were males. (Fig.2) Most of the burn injury occurred in kitchen $(61.5 \%)$, followed by living room (20.6\%) and open space (8.6\%). (Table 4) Accidental burn injuries were most common (74.4\%) amongst all the cases. (Table 5) Maximum number of accidental burn injuries were due to burst of kerosene stove $(23 \%)$, followed by clothes catching fire from chullha and stove during cooking. 
Around $1 / 6^{\text {th }}$ of burn deaths were suicidal using kerosene. (Table 6) Majority of the victims (51.5\%) wore synthetic dress at the time of incident (Table 7) on further gender wise distribution, majority of the females $(58.3 \%)$ wore synthetic dress while most of the male victims (54.9\%) wore cotton dress (Fig.3).

Table 1: Types of burn (thermal \& physical) injury

\begin{tabular}{|l|c|c|c|}
\hline Causes & Male & Female & Total \\
\hline Flame/Burn & 52 & 226 & $278(92.4 \%)$ \\
\hline Scald & 4 & 2 & $6(2 \%)$ \\
\hline Electrocution & 8 & 1 & $9(3 \%)$ \\
\hline Lightening & 7 & 1 & $8(2.6 \%)$ \\
\hline Total & 71 & 230 & $301(100 \%)$ \\
\hline
\end{tabular}

Table 2: Age wise distribution

\begin{tabular}{|l|l|l|l|}
\hline Age (years) & Male & Female & Total \\
\hline $0-10$ & 4 & 7 & $11(3.6 \%)$ \\
\hline $11-20$ & 7 & 72 & $79(26.2 \%)$ \\
\hline $21-30$ & 26 & 94 & $120(39.8 \%)$ \\
\hline $31-40$ & 19 & 28 & $47(15.6 \%)$ \\
\hline $41-50$ & 9 & 12 & $21(7 \%)$ \\
\hline $51-60$ & 3 & 8 & $11(3.6 \%)$ \\
\hline $61-70$ & 2 & 8 & $10(3.3 \%)$ \\
\hline$>70$ & 1 & 1 & $2(0.7 \%)$ \\
\hline Total & 71 & 230 & $301(100 \%)$ \\
\hline
\end{tabular}

Table 3: Geographical distribution

\begin{tabular}{|l|l|l|l|}
\hline Area & Male & Female & Total \\
\hline Rural & 56 & 168 & $224(74.4 \%)$ \\
\hline Urban & 15 & 62 & $77(25.6 \%)$ \\
\hline Total & 71 & 230 & $301(100 \%)$ \\
\hline
\end{tabular}

Table 4: Place of incidence

\begin{tabular}{|l|c|c|c|}
\hline Place of occurrence & Male & Female & Total \\
\hline Kitchen & 19 & 166 & $185(61.5 \%)$ \\
\hline Living Room & 18 & 44 & $62(20.6 \%)$ \\
\hline $\begin{array}{l}\text { Living Room Cum } \\
\text { Kitchen }\end{array}$ & 8 & 12 & $20(6.6 \%)$ \\
\hline Open Space & 18 & 8 & $26(8.6 \%)$ \\
\hline Industries & 8 & 0 & $8(2.7 \%)$ \\
\hline Total & 71 & 230 & $301(100 \%)$ \\
\hline
\end{tabular}

Table 5: Manner of the injuries

\begin{tabular}{|l|c|c|c|}
\hline Manner & Male & Female & Total \\
\hline Accidental & 57 & 167 & $224(74.4 \%)$ \\
\hline Suicidal & 14 & 34 & $48(15.9 \%)$ \\
\hline Alleged Homicidal & 0 & 29 & $29(9.6 \%)$ \\
\hline Total & 71 & 230 & $301(100 \%)$ \\
\hline
\end{tabular}

Table 6: Causes of Burn injuries

\begin{tabular}{|l|c|c|c|}
\hline $\begin{array}{l}\text { Source of Burns (History } \\
\text { based) }\end{array}$ & Male & Female & Total \\
\hline Blast of Kerosene Stove & 9 & 60 & $69(23 \%)$ \\
\hline $\begin{array}{l}\text { Clothes caught fire from } \\
\text { chullha }\end{array}$ & 0 & 41 & $41(13.6 \%)$ \\
\hline
\end{tabular}

\begin{tabular}{|c|c|c|c|}
\hline $\begin{array}{l}\begin{array}{l}\text { Clothes caught fire from } \\
\text { Stove }\end{array} \\
\end{array}$ & 5 & 24 & $29(9.6 \%)$ \\
\hline $\begin{array}{l}\text { Fire caught from lamp while } \\
\text { asleep }\end{array}$ & 9 & 12 & $21(7 \%)$ \\
\hline Fire caught from straw & 3 & 6 & $9(3 \%)$ \\
\hline Gas leakage & 1 & 8 & $9(3 \%)$ \\
\hline $\begin{array}{l}\text { Fire caught from mosquito } \\
\text { coil while asleep }\end{array}$ & 6 & 2 & $8(2.7 \%)$ \\
\hline $\begin{array}{l}\text { Fire caught from Deepa } \\
\text { (worship lamp) }\end{array}$ & 0 & 7 & $7(2.3 \%)$ \\
\hline Fire from blast of crackers & 4 & 0 & $4(1.3 \%)$ \\
\hline While saving a victim & 3 & 0 & $3(1 \%)$ \\
\hline Blast of LPG cylinder & 0 & 1 & $1(0.3 \%)$ \\
\hline Blast of Boiler & 1 & 0 & $1(0.3 \%)$ \\
\hline Suicidal burn using kerosene & 14 & 34 & $48(15.9 \%)$ \\
\hline $\begin{array}{l}\text { Alleged Homicidal burn } \\
\text { using kerosene }\end{array}$ & 0 & 29 & $29(9.6 \%)$ \\
\hline Scald from hot water/liquid & 1 & 4 & $5(1.7 \%)$ \\
\hline Lightening & 7 & 1 & $8(2.7 \%)$ \\
\hline Electricity & 8 & 1 & $9(3 \%)$ \\
\hline Total & 71 & 230 & $301(100 \%)$ \\
\hline
\end{tabular}

Table 7: Material of wearing apparel

\begin{tabular}{|l|c|c|c|}
\hline $\begin{array}{l}\text { Nature of wearing } \\
\text { Apparel }\end{array}$ & Male & Female & Total \\
\hline Cotton & 39 & 79 & $118(39.2 \%)$ \\
\hline Synthetic & 21 & 134 & $155(51.5 \%)$ \\
\hline Unknown & 11 & 17 & $28(9.3 \%)$ \\
\hline Total & 71 & 230 & $301(100 \%)$ \\
\hline
\end{tabular}

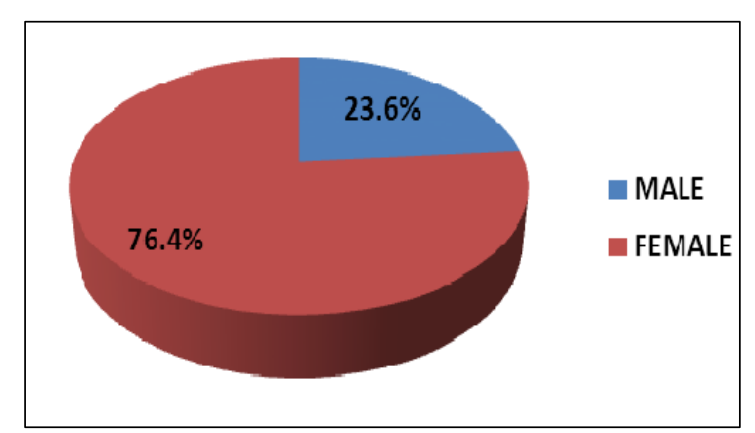

Fig. 1: Gender wise distribution

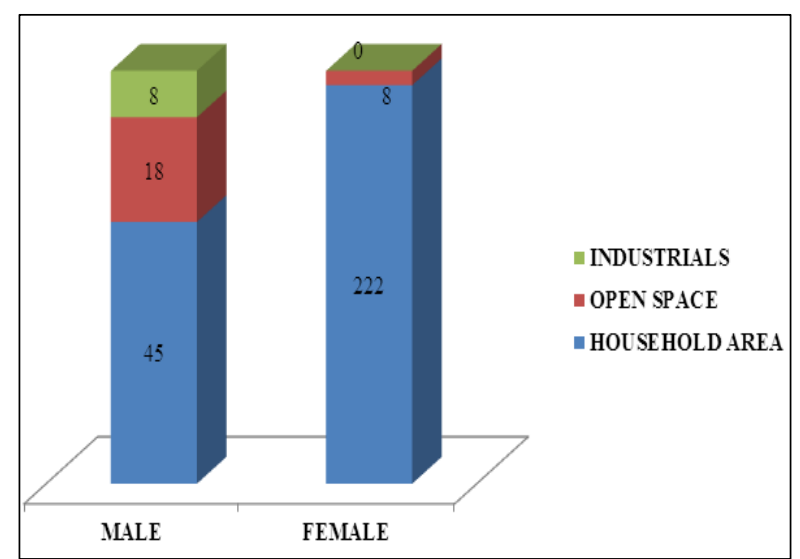

Fig. 2: Place of occurrence (Gender wise analysis) 


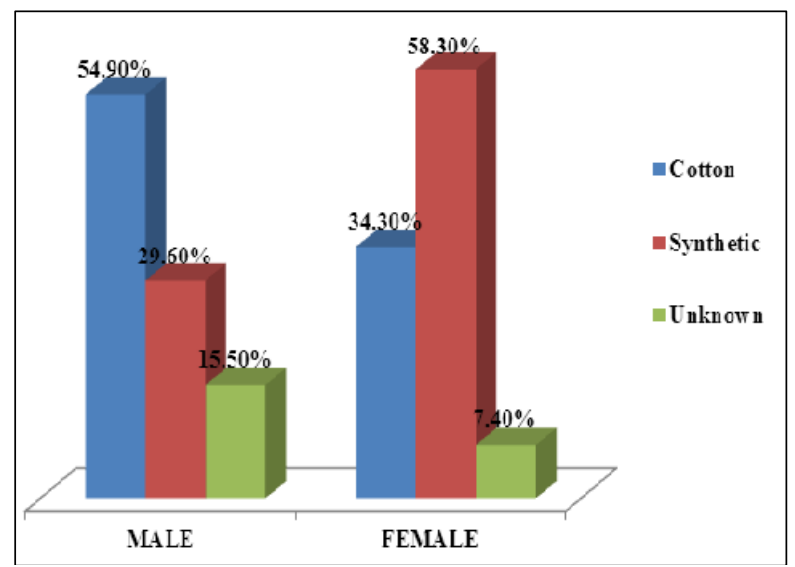

Fig. 3: Material of wearing apparel (gender wise analysis)

\section{Discussions}

Thermal injuries can be produced by local application of dry heat (flame burns), moist heat (scalds), electrocution (joule burns or flash burns) and by lightening. On analysing the types of thermal injury, it was found that most number of cases is due to flame burns, followed by electric burns, lightening and least number of cases due to scalds. In the matter of lightening and electric injury, males outnumber female victims.

Working on this, Attia A.F et $\mathrm{al}^{2}$, Ragheb $\mathrm{S}$ et $\mathrm{al}^{3}$, Mzezewa S et $\mathrm{al}^{4}$, Olaitan P B and Jiburum B C ${ }^{5}$, Hosseini R.S. et $\mathrm{al}^{6}$ reported quite similar results. In India also Kumar V. et $\mathrm{al}^{7}$, Mangal H.M. et al ${ }^{8}$, Jaiswal AK et al ${ }^{9}$, Singh P., Dasari $\mathrm{H}^{10}$, Mir M. A. et al ${ }^{11}$ and few others found flame as the most common causative agent.

However Hilal A. et al ${ }^{12}$ and Hamayun $\mathrm{M}$ et al ${ }^{13}$ stated the most common cause of thermal injuries to be scalds, which is contradictory to our finding.

The high incidence of flame burns may be explained by use of oil lamps, candle for lighting, substandard kerosene and gas stoves, use of open coal and wood fires, chullha for warmth and cooking in villages and use of pressure stoves for cooking in urban areas.

On gender wise analysis, it is observed that majority of victims are females with a female to male ratio of $3.2: 1$, which is very similar to the studies conducted by Babladi $\mathrm{P}$ I et al ${ }^{14}$,Chakraborty S et al ${ }^{15}$, Kaulapur V V et al ${ }^{16}$, Chawla R. et al ${ }^{17}$,Jain R et $\mathrm{al}^{18}{ }^{1}$.Haralkar S J, Tapare V S, Rayate M $\mathrm{V}^{19}$, Singh P, Dasari $\mathrm{H}^{10}$, Gupta R et $\mathrm{al}^{20}$,Mir M. A. et al ${ }^{11}$. In contrast to our study Shkrum and Johnston ${ }^{21}$ in Canada, Olaitan P B and Jiburum B C ${ }^{5}$, Hilal A et $\mathrm{al}^{12}$ noticed male preponderance.

The female preponderance to the fatal incidences is because of their involvement in kitchen work and continuous exposure to an open source of fire. The other reasons which contribute significantly are traditional clothing pattern in Indian women, illiteracy, lack of awareness, mental stress, suicidal and dowry deaths.

The peak incidence is observed in the age group 21-30 years, followed by 11-20 years. On sex wise analysis, the susceptible age group for both male and female is 21-30 years followed by age group of 11-20 years in female and
31-40 years in males. The current study revealed almost similar finding with little variation to the studies conducted by Shaha K.K. and Mohanty S N ${ }^{22}$,Memchoubi Ph., Nabachandra $\mathrm{H}^{23}$, Jaiswal AK et $\mathrm{al}^{9}$, Kaulapur V V et al ${ }^{16}$,etc.

In contrast, studies conducted by Singh $\mathrm{D}$ et $\mathrm{al}^{24}$, Khanagwal V et al ${ }^{25}$, Ghaffar U.B. et al ${ }^{26}$, Chakraborty S et $\mathrm{al}^{15}$, Haralkar S J, Tapare V S, Rayate M V ${ }^{19}$, Gupta R et $\mathrm{al}^{20}$, Tedeschi C.G ${ }^{27}$, Abu Ragheb S et $\mathrm{al}^{3}$, Liu EH et $\mathrm{al}^{28}$, Hilal A. et al ${ }^{12}$ are not consistent with our study.

The increased incidences are observed in the most productive and young age group of 21-30 years as they are generally active and exposed to hazardous situations. Usually in India, females marry in their late adolescent and engaged in cooking at home and wear clothes like sarees, dupatta which catch fire easily. Male preponderance in the $3^{\text {rd }}$ and $4^{\text {th }}$ decade of life can be attributed to their place of work and occupation.

On evaluating geographical distribution of burn cases, it is found that quite most of the victims are from rural areas irrespective of gender. Similar findings of rural predominance is also observed by Singh D et al ${ }^{24}$, Batra A.K. ${ }^{29}$, Zanjad $\mathrm{N}$ and Godbole $\mathrm{H} \mathrm{V}{ }^{30}$ Dasari $\mathrm{H}$ et al ${ }^{31}$, Ghaffar U.B. et $\mathrm{al}^{26}$, Haralkar S J et $\mathrm{al}^{19}$, Gupta $\mathrm{R}$ et $\mathrm{al}^{20}$ and Mir M. A. et al ${ }^{11}$ However studies conducted by Jaiswal AK et al ${ }^{9}$ Chawla R. et al ${ }^{17}$ and Singh $\mathrm{P}$ et al ${ }^{10}$ reported that most of the males belonged to urban areas.

The high incidence of fatal burns in the rural areas can be explained by use of kerosene oil lamps for light in the villages, use of substandard gas stoves, open coal and wood fires for cooking, lack of safety measures and delay in approaching medical attention etc.

On analysing the place of occurrence of the fatal incidence, it is observed that almost all females suffered the injury inside the four walls of their own house while all industrial burn victims are males. On further categorisation, it was evident that kitchen is the most common site of incidence, followed by living room. While majority of female victims contracted the fatal injury in the kitchen, the male victims showed almost equal frequency in kitchen, living room or open space outside home. All the industrial burn victims are male. The present study got findings almost similar to the studies conducted by Attia A.F, et al ${ }^{2}$, Kumar V., et al ${ }^{32}$, Dashari $\mathrm{H}$ et $\mathrm{al}^{31}$, Gupta $\mathrm{R}$ et $\mathrm{al}^{20}$ and Mir M. A. et $\mathrm{al}^{11}$. Whereas in contrast to our study, Mago V et al $^{33}$ reported open space is the most common site of incident.

A great majority of fatal female victims contract the thermal injury in the kitchen space because female spent most of the time in kitchen and it is also a secluded place for suicidal purpose. It can be a plan of the perpetrator to escape from homicide allegation.

Analysing the history collected from the accompanying persons/relatives/police and post-mortem findings, it is found that most of the fatal burn injuries are accidental in nature irrespective of the gender.

On further analysing the different source of thermal injuries the present study reveals that maximum number of 
burn injuries are due to alleged burst of kerosene stove, followed by suicidal burn using kerosene and clothes catching fire from chullha during cooking, which shows a female preponderance. In males, around $1 / 5^{\text {th }}$ of the burn injuries are due to suicidal burn using kerosene while around $15 \%$ females had adopted the same method to commit suicide. There is an allegation of homicide in around $12.6 \%$ of female victims. All the victims of cracker blast, electrocution and lightning are males. The findings of the study are very similar to studies conducted by Tedeschi ${ }^{27}$, Attia A.F et al ${ }^{2}$, Hosseini R.S. et al ${ }^{6}$ Singh D et al ${ }^{24}$, Ambade V.N. et al ${ }^{1}$, Zanjad $\mathrm{N}$ and Godbole $\mathrm{H} \mathrm{V}^{30}$, Jaiswal AK et al ${ }^{9}$, Ghaffar U.B. et al ${ }^{26}$, Chakraborty $\mathrm{S}$ et al ${ }^{15}$, Chawla R. et al ${ }^{17}$, Gupta $R$ et al ${ }^{20}$ with little variations. This can be attributed to the place, pattern and type of work with easy availability of the inflammable substance.

Regarding nature of wearing apparel of the burn victims at the time of incident, it is observed that majority of the victims wore synthetic clothes which is very similar to studies conducted by Mago V et $\mathrm{al}^{33}$, Haralkar S J, Tapare V $\mathrm{S}$, Rayate $\mathrm{M} \mathrm{V}^{19}$. On gender wise analysis, it reveals that majority of the females wore synthetic dress and most of the male victims wore cotton dress. Synthetic clothes catch fire easily and flare upward resulting in difficulty for the victim to save oneself from the burn injury.

\section{Conclusion}

In our study we have concluded that majority of the victims are females and are from rural background. Domestic fire is the most common cause and cooking is the commonest activity when incident took place. Kerosene is found to be the most common offending agent and stove burst being the main cause. Majority of the victims wore synthetic clothes. Hence public awareness regarding the safety precautions to prevent such incidents should be encouraged. The cooking medium like wooden chullha and unsafe kerosene pressure stoves should be replaced by much safer LPG stoves with proper safety training. Public awareness has to be created regarding first-aid in such burn cases at primary health care level and anganwadi workers in villages. The hospital set up at PHC and CHC level should be well equipped to handle and refer the cases for treatment. The transport facility should be improved from the rural areas. The houses and kitchen should be made of pucca house with better ventilation. Social activists and NGOs should create public awareness to avoid early marriage in female and employment of males after proper physical fitness.

\section{Source of Funding: None.}

\section{Conflict of Interest: None.}

\section{References}

1. Ambade V.N., Godbole H.V. Study of burn deaths in Nagpur, Central India. Burns 2006, Nov;32(7):902-8.

2. Attia A F, Sherif A A, Mandil A M et al . Epidemiological and Sociocultural study of burn patients in Alexandria, Egypt. Eastern Mediterranean Health Journal 1997;3(3).
3. Ragheb S, Qaryoute $\mathrm{S}$ et al. Mortality of the burn injuries in Jordan. Burns 1984;10(6):439-43.

4. Mzezewa S, Jonsson K, Aberg M, Salemark L. A prospective study on the epidemiology of burns in patients admitted to the Harare burn units. Burns 1999;25(6):499-504.

5. Olaitan P.B., Jiburum B.C. Annals of burns and fire disasters 2006;19(2).

6. Hosseni R.S., Askarian M. Assadian O. Epidemiology of hospitalized female burn patients in a burn centre in Shiraz. Eastern Mediterr Health J 2007;13(1):113-18.

7. Kumar V., Mohanty M.K., Sarita. Fatal burns in Manipal area: A 10 years study. J Forensic Leg Med 2007; 14 (1):3-6. Also available from www. JFLM Journal org / article / S 1353-1131 (05) 00170 - 7/ Abstract.

8. Mangal H.M., Pathak A., Rathod J.S. The Fire is Both "A Blessing and scourge to the mankind". JIAFM 2007;29 (4):757.

9. Jaiswal A.K, Aggarwal H., Solanki P.S, Mathur RK, Odiya Sudarshan. Epidemiological and socio-cultural study of burn patients in M.Y. Hospital, Indore, India. Indian J. Plast Surg 2007;40:158-63.

10. Singh P, Dasari H. Profile of Burn Cases at Government Medical College and hospital, Chandigarh. IJFMT 2012;6(1):56-9.

11. Mir M.A., Anjum S., Mir R.A., Sheikh G., Reshi F.A. Etiological And Demographic Profile Of Burn Injury in Kashmir Valley. The Internet Journal of Plastic Surgery 2012;8(1)

12. Hilal A, Cekin N, Arslan M, Gulmen MK. Deaths due to Burns in Adana,Turkey. Burns 2008;34(7):982-5.

13. Hamayun M, Hussain Z, Khan Dilawar, Asadullah, Aziz K. Epidemiology of Burn injuries - Mortality and Morbidity in Hazara Division NWFP: Pakistan J Med Health Sci. 2010;4(1):53-6.

14. Babladi P.I., Vijayanath V, Vijayamahantesh S.N. Medico Legal Update 2010;10(2).

15. Chakraborty S, Bisoi S, Chattopadhyay D, Mishra R, Bhattacharya N, Biswas B. A study on demographic and clinical profile of burn patients in an Apex Institute of West Bengal. Indian J Public Health 2010;54:27-9.

16. Koulapur V. V., Yoganarsimha K., Gouda H., Mugadlimath A.B., Kumar V.A.G. Analysis of fatal burn cases- a five year study at Sri B M Patil Medical College, Bijapur, Karnataka. Medico-Legal Update 2011;11(2):107-9.

17. Chawla R., Chanana A., Rai H., Aggarwal A.D., Singh H., Sharma G. Clinico - pathological profile in Deaths due to Burns. JIAFM 2011;33(1):14-7.

18. Jain R., Johari A., Dhanak K. L. Factors Influencing Mortality in Flame Burn Cases - A Medicolegal study. Medico-Legal Update. 2011; 11(2):42-5.

19. Haralkar S J, Tapare V S, Rayate M V. Study of SocioDemographic profile of Burn cases admitted to Shri Chhatrapati Shivaji Maharaj General Hospital, Solapur. National J Community Med 2011;2(1).

20. Gupta R, Kumar V, Tripathi SK. Profile of the Fatal Burn Deaths from the Varanasi Region, India. J Clin Diagn Res. 2012;6(4):608-11.

21. Shkrum MJ and Johnston K. Fire and suicide: A three year study of self immolation deaths. J Forensic Sci 1992;37(1):208-21.

22. Shaha K.K, Mohanty S. Alleged Dowry Death. A study of homicidal deaths. Med Sci. Law 2006;46(2):105-10.

23. Memchoubi Ph., Nabachandra H. A study of Burn deaths in Imphal. JIAFM 2007;29(4):131-4.

24. Singh D, Singh A., Sharma A.K, Sodhi L. Burn Mortality in Chandigarh zone: 25 years autopsy experience from tertiary care hospital of India. Burns 1998;24(2):150-6. 
25. Khanagwal V.P., Paliwal P.K., Yadav D.R. Evaluation of burn deaths at medical college Rohtak. JIAFM 95-98.

26. Ghaffar U.B., Husain M, Rizvi S.J. Thermal Burn: An Epidemiological prospective study. J Indian Acad. Forensic Med 2008;30(1):10-4.

27. Tedeschi C. G, Eckert W.G, Tedeschi L.G. Forensic Medicine a study in trauma and environmental hazards 1977;1:715-72. W.B Saunders Company.

28. Liu EH. A three year prospective audit of burns patients treated at the Western Regional Hospital of Nepal. Burns 1998;24 (2): 129-33

29. Batra A.K. Burn Mortality: Recent trends and sociocultural determinants in rural India. Burns 2003;29(3):270-75.

30. Zanjad N, Godbole H V. JIAFM. 2007;29(3).
31. Dasari H., Kumar A., Sharma B.R. Burns septicaemia-The leading cause of burn mortality. JPAFMAT 2008;8(2):10-86.

32. Kumar V. Tripathi C.B. Burnt Wives: A study of homicides. Med Sci Law 2004;44:1.55-60,22-24.

33. Mago V, Yaseen M, Bariar L.M. Epidemiology and Mortality of Burns in JNMC Hospital, AMU Aligarh: A 5 year study. Indian J community Med.2004;29(4):187-91.

How to cite this article: Nayak P K, Mohanty SK, Behera P. A Prospective study of avoidable domestic factors in fatal thermal injuries in a tertiary care hospital. Int $J$ Forensic Med Toxicol Sci 2019;4(4):120-4. 